\title{
FOR MAINTAINING DIVERSITY JURISDICTION
}

\author{
JOHN P. FRANK $\dagger$
}

THIS article is dedicated to "The Judge"-Charles Clark. Whether by daily contact or occasional correspondence, I have felt Judge Clark's strength and guidance for nearly all of the twenty-five years we commemorate today. In the world of academics or judges in which I have known him, almost everyone has integrity, but his is the ultimate. Here is a man who has never once consulted his self-interest about anything. Association with him is a continuing postgraduate course in absolute honesty and flawless courage. $\mathrm{He}$ is huge in all he does, and a giant in his special interests-federal procedure and federal courts. I am proud to be able to write in his honor on a topic in which he has deep interest, and to know that he shares the conclusions I have reached.*

The American Law Institute proposals on federal jurisdiction recommend revision of the Judicial Code to eliminate between fifty and sixty per cent of the present diversity cases. ${ }^{1}$ These would be transferred from the federal to the state courts. I would eliminate substantially none of these cases, and so present an opposing point of view.

The principal devices suggested for cutting the diversity jurisdiction are, first, the elimination of all cases brought by residents of the state in which they sue regardless of the diversity of the defendant; and second, a bar against suits by foreign corporations which have operated in a state sufficiently to have become "permanently established" there. The details of the proposals, and of the attendant revisions of process and venue are put outside this discussion. Assume the point of view, and the execution is admirable; the issue is the point of view.

tMr. Frank is a member of Lewis, Roca, Scoville, Beauchamp \& Linton, Phoenix, Arizona.

*I am authorized to state that in addition to Judge Clark, Judge J. Skelly Wright, of the Court of Appeals for the District of Columbia; Professor James W. Moore, author of Moore's Federal Practice (1960) and Professor of Law at Yale University; and Professor Charles A. Wright, author of the current edition of Barron \& Holtzoff, Federal Practice and Procedure (1961) and Professor of Law at the University of Texas, concur generally in the conclusion here reached.

1. The ALI has been requested by the Chief Justice of the United States to prepare extensive proposals for a possible revision of the Judicial Code. These proposals have been prepared by an able committee with Professor Richard Field of Harvard as Reporter. The introductory two or three sections of that Code were favorably considered at the May, 1963 meeting of the ALI. While, insofar as the Institute itself is concerned, the work is just beginning, one of the provisions approved did involve the principle of a substantial cut in the jurisdiction. 
The most striking deficiency of the proposal for change is the total absence of any major functional reason for making it. Substantial jurisdictional changes normally originate in a felt and usually acute social need. The major jurisdictional changes in the country's history have always originated because someone was dissatisfied with a practical situation. They did not stem just from an intellectual conviction that the system, if changed, would be more logical, more reasonable in its structure. I do not decry either reason or logic; but neither is enough by itself. There must be reason plus genuine, felt need. The Federalists extended jurisdiction in 1801 to make jobs for the faithful and to control the policies of the Republicans. The Jeffersonians in 1802 abolished that same jurisdiction for the reverse reasons. Chief Justice Marshall first extended jurisdiction to corporations in order to aid expanding commerce, and a subsequent Court completed the job because Marshall had not sufficiently anticipated how much protection this commerce would come to need. The anti-expansionists opposed this development because on the merits they were against banks and other corporations and did not want to aid them. Chief Justice Taney extended the admiralty jurisdiction to inland streams because of a felt need to aid transportation. The least understood change is the most important of all, the extension of the federal question jurisdiction by the Act of 1875 . The act slipped through Congress without significant discussion; and we can only assume that it was intended to meet the need created by the great simultaneous expansion of state regulation of business. ${ }^{2}$ A jurisdictional change may not always be designed to effect results external to the court system. It may also be designed for reasons of judicial administration. For example, the Certiorari Act of 1925, giving the United States Supreme Court a largely discretionary jurisdiction. was intended to relieve that Court of quantitative burdens it could not carry.

Now it is proposed to cut the federal diversity jurisdiction by more than half. We have utilized this jurisdiction since 1789. If now it should go, let it go. We do not shrink from warranted change because it is drastic, and habit must not be elevated to principle. But surely if we are to make this change there should be some affirmative, solid, practical reasons for doing so. Something about the present system ought to be working badly before it is cured; the doctors should diagnose an illness before prescribing a remedy.

In the two hundred page ALI "Study of the Division of Jurisdiction Between State and Federal Courts," I find only one paragraph asserting a social or practical reason for restricting the jurisdiction-a highly general statement that federal justice is being delayed by an expanding workload which leads to purportedly undesirable pressure for expanding the federal court system. Just how and where the diversity cases are causing this result and just why an expansion to take care of it is undesirable is left to unarticulated major premises.

2. In the Senate, the bill was introduced on January 5,1875 , reported from the Judiciary Committee two weeks later, and passed on January 26th without relevant discussion. It passed the House a few days later with irrelevant discussion. Frankforter \& Landrs, The Business of the Supreme Court (1927). 
So nearly as this writer knows, the system is working well throughout the country. Procedures are generally satisfactory, results good. If there is anywhere a complaint against the operation of the diversity system based on an assertion that injustice is being done through its working, I have not heard it. In my own jurisdiction, Arizona, I took an informal poll of leading trial lawyers throughout the state, largely restricted to practitioners who are in some court or working on some litigation, state or federal, almost every week and usually every day of their lives. More than eighty per cent report a desire to keep the federal jurisdiction intact, and of the minority, not one complains of any injustice under the present system. This, in a jurisdiction which can usually justly claim to be alert to need for change, and which on matters of procedure is one of the most progressive in the country.

\section{A. Historical Considerations}

It must be freely conceded that the diversity jurisdiction originated in premises of dubious validity and that it has survived a series of gross abuses, now largely corrected. The original federal court jurisdiction was almost entirely permissive; the Congress was under no obligation to create federal trial courts at all, and could have left all original matters except those in the Supreme Court to the States. And yet the Constitution did permit the creation of federal courts and the grant to them both of diversity and federal question jurisdiction, and the first Congress did choose to take up the option. It granted jurisdiction for private, civil cases in diversity only.

Why? The need arose from a fear of prejudice against out-of-staters engaged in regional business. I have developed in some detail elsewhere, based on a study of all generally available pre- 1787 reports, that this was largely a gloomy anticipation of things to come rather than an experienced evil; but nonetheless, there it was. ${ }^{3}$

The diversity jurisdiction in the first 150 years of its life had its successes and its abuses. The successes were substantial-the disposition of a good amount of important commercial business; the furnishing of the Supreme Court with enough to do to keep it busy and finally more than busy, thus permitting it to develop as a national institution; the nationalizing effect of the entire judicial operation which, to a degree at least, helped unify the country.

But the abuses were serious. First, jurisdictional manipulations furnished an easy device for depriving states of initial opportunities to pass on matters of their own policy. Second, the class biases of federal judges led to gross abuses both to the growing labor movement as an institution and to the rights of injured workers in an expanding industrial economy. Third, the great error of Swift v. Tyson ${ }^{4}$ and the federal choice of law permitted the gross abuse of jurisdiction shopping. It invited the manipulation of cases to put them where the results would be controlled by the choice of court.

3. Frank, Historical Basis of the Federal Judicial System, 13 LAw \& ConteMr. Prob. 3, 14-28 and particularly 22-28 (1948).

4. 16 Pet. (41 U.S.) 1 (1842). 
If these abuses could not have been controlled, the abolition of the whole diversity jurisdiction should have followed. But creative leadership did devise controls, and the abuses were very largely eliminated. The legitimization of federal question litigation in 1875 eliminated much of the purpose of phony diversity intended to raise federal questions. Such decisions as Hazes v. Oakland ${ }^{5}$ helped check the gross abuse of the manipulated case. More fundamentally, the Johnson Act largely took the federal courts out of the utility regulation field, and case developments following its policy have greatly minimized the conflict of jurisdictions. In the labor relations field, the Equity Rules of 1912 were some improvement, but not nearly enough; the Norris-LaGuardia Act in 1932 largely ended government by injunction. In the tort cases the rise of industrial compensation, the passage of the FELA and Jones Act, and the general revitalization of juries by the Supreme Court has almost totally eliminated the earlier abuses. Finally, Erie v. Tompkins ${ }^{6}$ has largely ended the evil of jurisdiction shopping. There will never again, we trust, be another Black and White Taxicab case. ${ }^{7}$

Nonetheless, these abuses leave a residue which contributes to the present push for great change. The past evils in diversity are not evils of an ancient yesterday. Most of the cures are the product not only of this Century but of the years since 1930 . These abuses were gross enough to warrant, if necessary, the total abolition of diversity. Able and impartial observers for the years 1890 to 1930 could very reasonably develop severe prejudices against this jurisdiction. They did, and many of them have greatly influenced the thinking of the present advocates of change.

But the major premises of that prejudice deserve tight re-examination. It is possible- I think it is true-that the abuses of diversity have been pretty well filed away, and that what is left is a worthy and useful device of public administration. The anti-diversity attitude has become a habit. Those who wish to terminate, suspend, or cut down this valuable federal service would do well to re-examine and re-state their major premise in depth.

\section{B. The Values of Diversity}

The first great value of diversity is its disposition of something on the order of fifteen thousand disputes a year to the general satisfaction of those who need their disposition. Of course not all litigants are content with results; doubtless human impulse leaves at least half of them unhappy. Nor are all federal judges wiser or abler or all federal procedures more satisfactory than state procedures. The federal bench has its share of incompetents, tyrants and fools; I can personally recall appearances before some of each. Occasionally a regional area, in which highly political appointments have been made in response to local and occasionally unworthy political impulses, found itself with a wholly inferior

5. 104 U.S. 450 (1882).

6. Erie R.R. v. Tompkins, 304 U.S. 64 (1938).

7. Black \& White Taxicab \& Transfer Co. v. Brown \& Yellow Taxicab \& Transfer Co., 276 U.S. 518 (1928). 
bench. Some federal procedures, such as the restriction of cross-examination to the scope of direct, may be inferior to state procedures.

Hence I recite here no cult of the superman. But, with a high degree of uniformity, the system has been generally satisfactory to those living under it. The litigant who loses rarely feels with much conviction that he would have been better off in a different system. Where political considerations make the federal judges poor, they are likely to make the local judges even worse. There is a general feeling that justice in federal courts is being well administered. There is no widespread, obvious abuse to be corrected.

The second great plus is the educational value of having two systems in interaction. This value is felt at both national and local levels. The success of the federal rules has led to their widespread emulation in the states, and the federally sponsored process of continued revision is keeping state procedure moving as well. This process is of tremendous importance because the necessary spade work on procedural studies may require national attention and national subsidization. The costs of a discovery study, as is now in progress in the federal system, could not be easily borne locally. And interaction is by no means a one-way street. The present practice encourages the federal system to borrow state improvements and experiments. Many of the recent changes in federal procedure came from the states. A recent change in the federal rule on process stems from progress in Illinois; an impending change in parties from developments in Michigan; and a recent change in directed verdict procedure from a predecessor rule in Arizona. In Arizona again, an impending federal rule of practice on pre-trial is likely to follow the state rule; if it varies somewhat and the variances prove useful, the state rule will probably be changed to conform to it. The state practices on the time and manner of taking exceptions to jury instructions are working their way into the local federal practice, and certain federal devices of encouraging a businesslike dispositon of cases find their way back to the state court.

Those who would drastically cut the diversity jurisdiction do not doubt the validity of the point made here. They think merely that there will be enough federal business left to permit the same effect. The proposition is not demonstrable one way or the other, and I can only say that I do not myself think so. We need the substantial bulk, the regular exposure to concurrent jurisdiction, to get the best effect of the interaction. The federal question cases are more likely to be for specialists in antitrust or FELA or taxes. The inclusion of the full gamut of commercial and tort cases puts the whole litigation bar into federal courts.

The very fact that the same cases are on both sides heightens the value of comparative experience. Recently Judge J. Skelly Wright of the District of Columbia Court of Appeals visited our state to give a demonstration before a Bar Committee of his way of administering a pre-trial. The example chosen was a routine tort case, one which had in fact been in our state.court. In a brilliant demonstration, Judge Wright taught our Bar and our state judges 
who were in attendance a good deal worth knowing about his handling of these procedures. If the fundamental $\mathrm{cog}$, the case itself, had not been interchangeable between the two systems, the teaching would not have been nearly as valuable. We need a duplicating experience to protect the flow of ideas.

Finally, there are elements of prejudice and competence deserving to be taken into account. A native given the practical alternative of having his suit against an out-of-stater in a particular county of his state system may well conclude that speed, ability, impartiality or plain convenience will be best served in the federal court. The out-of-state defendant is normally not hurt by this judgment, and the whole cause may benefit from it. There are other prejudices than the merely regional, and a litigant may believe that he escapes some of them in federal court. The suggestion has been made that the litigant, if dissatisfied with his state justice, should improve it, not escape it; but this is visionary. The litigant has a problem which needs solving now, not in the time of the Messiah ; and maintaining a concurrent system is one way of developing improvements in each of them.

\section{The Criticisms of Diversity Jurisdiction}

There are astonishingly few criticisms of diversity jurisdiction, and these are almost entirely unsupported by data or stated experience. First and most fundamental is an act of faith, an accepted and unexamined major premise that "state cases belong in state courts." This assumes a good deal. It assumes that there is such a phenomenon as a "state case," a kind of provincial fracas which should be kept happily local and free of federal contact. Why? In the week before penning these words, I filed a brief with the NLRB on whether three butchers in a local meat market should be classed with the Retail Clerks or with the Meat Cutters Union; prepared a complaint to the Labor Department in behalf of one plumber who appears not to have received his entitlement to back wages; and scheduled a deposition in a $\$ 250,000$ diversity case. My partners meanwhile processed securities matters, problems of the regulation of the distribution of blood plasma, and a question concerning the construction of a county road before other federal agencies. What is there in the genius of American Government by which some of these dispute-settling functions may be absolutely required to be federal, while the quarter of a million dollar law suit should not be federally settled even if one or both parties desire it ? $^{8}$

8. Related is the argument that the jurisdiction is "illogical" in that a citizen has the option of suing a diverse defendant in either the state or the federal court; and the diverse defendant may remove if he desires; the citizen in that case has a choice of courts. However, if the out-of-stater is plaintiff and chooses to sue the same citizen in state court, the citizen may not remove. Hence, it is said, the system makes no sense because the citizen has an option if he is plaintiff but not if he is a defendant.

Perhaps in this circumstance the cure would be to give the citizen the right to remove. I do not suggest it only because we are comfortably adjusted to the existing pattern and there is no really felt need for change. But, in any case, this is not very serious illogic. In both situations the out-of-stater has his option, and in both the plaintiff has the option, as well as the burden of going forward. And again, more fundamentally, there should be logic plus a real need to warrant the change. 
A second criticism is that inclusion of the diversity cases clogs federal courts and requires more judges. If so, why not have more judges? What, precisely, is the evil? So far as cost is concerned, these cases must go somewhere. The taxpayer as a legitimately wincing animal does not suffer drastically more by the choice of forum; indeed, the superior federal revenue sources may make the cost less burdensome on the federal side. Of course expansion is required for an expanding country. So is expansion of the post office, or any other federal service agency. Is there some solid, demonstrable reason to suggest that this expansion has any unhappier effects than any of the other expansions of a booming country?

Third is the ventriloquist's dummy criticism, the suggestion that requiring federal judges to be mouthpieces for state law will depreciate the quality both of justice and of those willing to participate in declaring it. This may have merit. When Erie v. Tompkins ${ }^{0}$ was decided, many of us worried about it for a time, and will recall a general fear during the 40 's that the decision might strangle creativity on the federal side of the bench. But by now this is a problem which, if problem it be, is beyond mere nervous fussing. The evil, if any, should be demonstrable. How many federal decisions show an atrophy of creativity for this reason? What are they? What good men have refused the office for this reason? How many?

In short, if there is an evil here, it should by now be a provable evil; and I at least have not seen even a start toward making such proof.

\section{CONCLUSION}

The attack on diversity jurisdiction is worse than wrong, it is obsolete. It beats a dead horse, seeking to cure an abuse which no longer exists.

What sense is there to it? We live in an age in which, for better or for worse, the federal government helps build the hospitals in which our children are born, contributes to the roads on which we bring them back to the house, regulates the price of the wheat which makes the bread which goes into their mouths, subsidizes the milk they drink in the grade school and helps build the college they attend. Their old age may depend upon their (federal) social security, their health upon a (federal) program. All these are recent things, products largely of this century. They may be for better or for worse-good Americans whose views I must respect as much as I do my own, and who take one stand or another on these issues. But in our daily lives, underlying all these strata of Federal participation in our every movement, lies one federal privilege which stems from General Washington, which James Madison helped to create, which has existed almost from the first minute of this Republic. That is the privilege of taking those disputes which involve citizens of different states into the courts of the federal system.

The system works well. There is no good reason for changing it.

9. Erie R.R. v. Tompkins, 304 U.S. 64 (1938). 